\title{
Analysis of Effects of Price, Service Quality, and Information Factors on Customer Satisfaction and Its Impact on the Commitment of Broadband Internet Customers
}

\author{
Arifatulloh Cakrabuana $^{1 *} \quad$ Mochamad Mukti Ali $^{2 *}$ \\ 1.Research Scholar, School of Magister Management, University Mercubuana, South Meruya Street No.1, \\ Jakarta, 11650 Indonesia \\ 2.School of Magister Management, University Mercubuana, South Meruya Street No.1, Jakarta, 11650 Indonesia
}

\begin{abstract}
This research was conducted with the aim of analyzing the effects of price, service quality, and information factors on customer satisfaction and its impact on the commitment of broadband internet customer. The sample used in this research was 200 respondents of MyRepublic broadband internet service customers taken with simple random sampling technique. The data analysis in this research was Structural Equation Model (SEM) which was carried out using Lisrel 8.80 program. The results showed that the price, service quality, and information quality factors had a direct and positive and significant effect on customer satisfaction and broadband internet customer commitment. Meanwhile, price, service quality, and information quality had an indirect, significant, and positive correlation to customer commitment but did not have an indirect correlation to customer satisfaction.
\end{abstract}

Keywords: price, information quality, service quality, customer satisfaction, customer commitment.

DOI: $10.7176 / \mathrm{EJBM} / 11-23-03$

Publication date: August $31^{\text {st }} 2019$

\subsection{Background}

In Indonesia particularly, the development of internet usage is increasing every year. Based on the results of research conducted by the Indonesia Internet Service Providers Association (Asosiasi Penyelenggara Jasa Internet Indonesia - APJII) in 2017 published on the official website (https://www.apjii.or.id/content/read/39/342/HasilSurvei-Penetrasi-dan-Perilaku-PenggunaInternet-Indonesia-2017), the development has been continuing to accelerate since 1998 and reached the highest increase in user growth in 2016 by 22.1 million. In 2017, the users had reached 143.26 million or $54.68 \%$ of the population in Indonesia.

From the development of internet service users which is increasing by the year, it is further pursed to find out the percentage of regions in the use of the internet. For the highest penetration area, Java still dominates $57.70 \%$ followed by Bali-Nusa Tenggara of $54.23 \%$ and Sumatra of $47.20 \%$. In addition, internet users in the world and especially in Indonesia are not only adults but also children, adolescents, and parents. Therefore, this research also explored information about internet usage based on age. The highest internet users are those in the 19-34 years age category of $49.52 \%$. While the next are those aged $35-54$, as many as $29.55 \%$. The use of the internet is varied besides students and offices and internet users ranging from low to high economic status.

Beside triggering the development of internet users and increasing penetration into remote areas in Indonesia, fixed broadband industry was pioneered by Indihome, a subsidiary of PT Telkom Indonesia. Indihome is also a market leader in fixed broadband. Currently, 70\% of user distribution of fixed broadband is owned by IndiHome, $27 \%$ is dominated by FirstMedia, $2 \%$ by MNCPlay, and MyRepublic Indonesia only has $1 \%$ of the total distribution.

\subsection{Problem Statement}

As we know, the majority of internet users in Indonesia come from strata $\mathrm{C}$ of lower middle-class. Therefore, internet users in Indonesia have a fairly high price sensitivity, so that this greatly affects competition in the internet industry in Indonesia. For fixed broadband category, several companies have implemented different pricing policies. For example, FirstMedia and MNCPlay focus on internet and TV products by promoting regional price models.

For this fixed broadband category, several companies have implemented different pricing policies. The strategy adopted by each fixed broadband company has caused customer disappointment, especially the fact that the price may rise at any time without firstly informed to the customer.

Information about subscription terms are not clearly communicated to the customer, so it also results in fear of subscription. In addition to price and unclear information, customers also expect excellent service quality. This is indicated by the increasing number of complaints. If the customers do not get what they are expected, they will shift to another internet service provider. This can be seen that the increasing number of unsubscribed customers every month. 


\subsection{Purpose of the Study}

The purpose of this research was to determine the effects of price, service quality, and information quality on customer satisfaction and customer commitment of Fixed Internet Broadband Operator MyRepublic using Structural Equation Model (SEM) analysis with Lisrel 8.80 program. The tests in this research were: (1) Data Quality Test: validity and reliability tests; (2) Assumptions Model SEM (Structural Equation Model) test including Confirmatory Factor Analysis (CFA) Test and Goodness of Fit Test; (3) Hypothesis Test.

\subsection{Research Questions}

The study was guided by the subsequent questions:

1. How does price, service quality and quality information have impact on customers satisfaction of fixed internet broadband?

2. How does price, service quality and quality information have impact on customers commitment satisfaction of fixed internet broadband?

3. How do customers satisfaction effects on the customer commitment of fixed internet broadband?

\subsection{Research Hypotheses}

The hypotheses obtained by the researchers are:

4. Price, quality of service, quality of information affects the customer satisfaction of Fixed Internet Broadband Operator of MyRepublic.

5. Price, quality of service, quality of information affects the customer commitment of Fixed Internet Broadband Operator of MyRepublic.

6. Customer satisfaction affects the customer commitment of Fixed Internet Broadband Operator of MyRepublic.

\subsection{Literature Review}

\subsection{Theorical Review}

Price. According to Hosang, et al, (2016: 161) price is money (plus some products if possible) needed to get a combination of products and services. Whereas, Kotler and Keller (2008) said that price is the easiest marketing program element to be adjusted. Moreover, price also communicates the value position intended by the company to the consumers about their products or brands. A product that is well designed and marketed can determine the price premium and get a large profit. According to Rondonuwu in Setyo (2017: 758), there are several indicators related to price: fixed price, affordability, fair price, price competitiveness, and discounts.

Quality of Service. Tjiptono (2002: 59) stated that service quality is the fulfillment of the needs and desires of customers as well as the accuracy of delivery to balance customer expectations. The definition of service quality according to Nasution (2004: 47) is the expected level of excellence and control over the level of excellence to meet customer desires. Service quality is a series of services provided to consumers. Service quality is a key measure of satisfaction. One of the standard instruments in assessing customer satisfaction is service quality including tangibility, reliability, responsiveness, assurance, and empathy (Parasuraman, et al., 1988).

Information Quality. Nugroho (2008: 15) stated that information is a useful knowledge for decision making. So, everything that can be used as a basis for decision making can basically be classified as information. According to Barnes and Vidgen in Alhasanah, et al (2014: 4), the quality of information is divided into several questions regarding the information that is accurate, reliable, timely, relevant, easy to understand, according to needs and according to format. While O'Brien (2006: 32-33) stated that there are 3 (three) dimensions of information quality, namely the time, the content, and form dimensions.

Customer satisfaction. According to Foster (2016: 6) "Consumers satisfaction basically covers the difference between expectations and perceived performance or results." Whereas, Putri and Nurcaya (2013: 923) stated that satisfaction is the level of feeling in which someone states the results of comparison of the performance of service products received and expected. Melinda in Saidani and Arifin (2012: 6) stated that there are three dimensions in measuring customer satisfaction universally, namely:

1. Attributes related to product is the satisfaction dimension related to the attributes of the product such as the determination of the value obtained by the price, the ability of the product to determine satisfaction, the benefits of the product.

2. Attributes related to service is the satisfaction dimension related to the attributes of the service, for example the promised guarantee, the process of service or delivery, and the process of resolving the problem.

3. Attributes related to purchase is satisfaction dimension related to the attributes of the decision to buy or not from the manufacturer such as ease of information, politeness of employees and also the reputation of the company.

Customer Commitment. Commitment is defined as a sense of ownership and consumer involvement with service providers that are similar to emotional ties in Ehsani \& Ehsani (2014: 53). Meanwhile according to Ellena (2011: 24), commitment is a valuable correlation that needs to be maintained continuously, in which each party is willing 
to work together to maintain this correlation. Customer commitment can be interpreted as a long-standing desire of the customer to maintain a valuable or beneficial correlation with the company. According to Capel and Ndubisi (2011), the indicators of commitment are as follows:

1. Adjusting to customer needs.

2. Offering personalized products to meet customer needs.

3. Flexible when products change.

4. Flexible in serving customer needs.

\subsection{Research Framework.}

Through the description in the theoretical framework, the researchers can comprehensively explain what variables are examined and from what theory the variables are derived, and why these variables are used as research. Based on a review of the theoretical basis that has been described previously and referring to previous research, the researchers illustrated the research framework as in Figure 1:

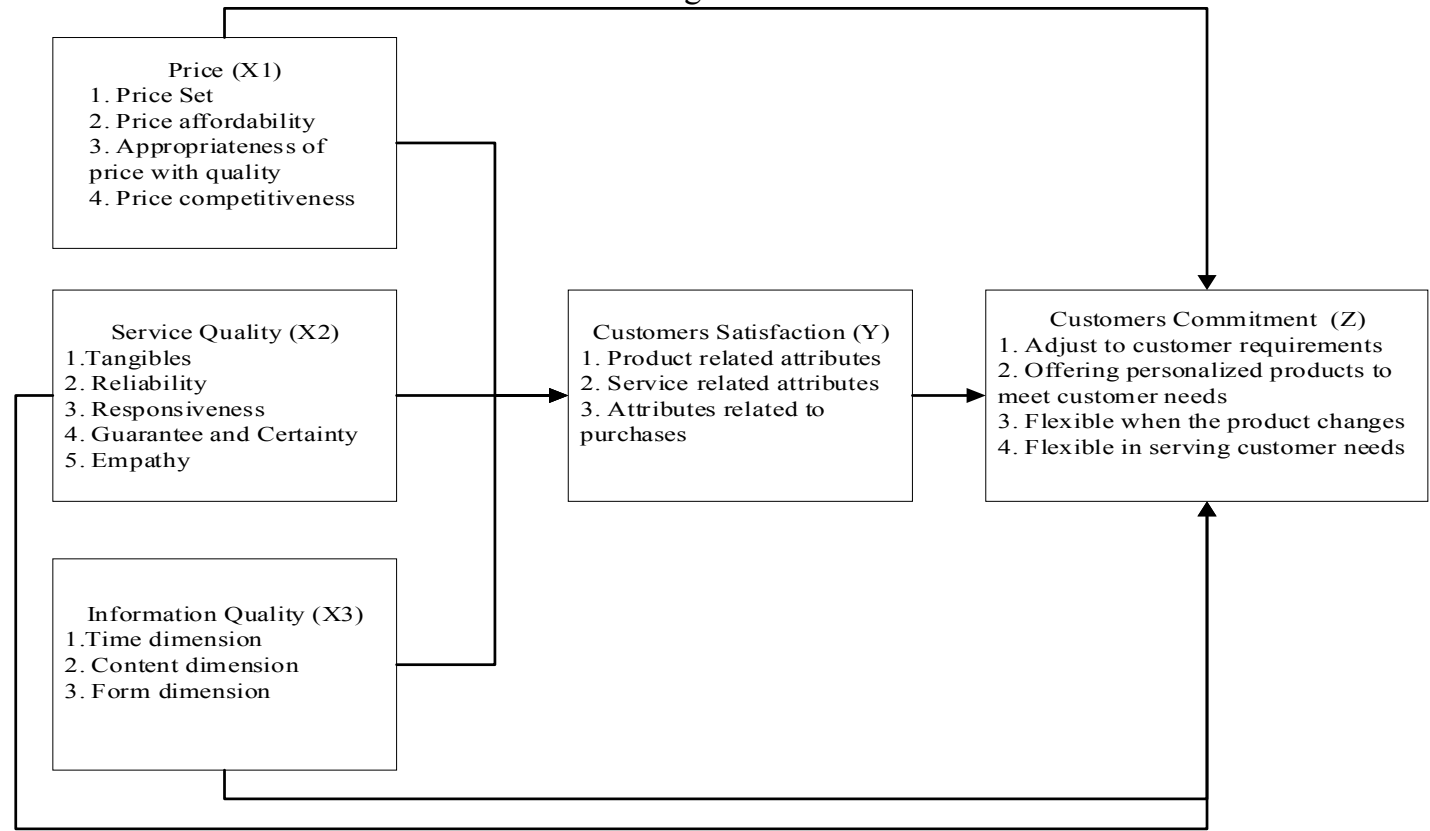

Figure 1. Research Framework

Source: The Researchers (2019)

The conceptual framework for this study comprises of the independent variables as price, service quality and Information quality. The dependent variable is customers satisfaction and customers commitments. The conceptual framework is shown in Figure 1.

\subsection{Research Methods.}

\subsection{Target Population and Sampling Design}

This research was conducted in Depok, West Java on March to December 2018. In this research, the population was all broadband internet and IPTV digital television customers in Depok, West Java area who have been subscribing for more than 1 year. The total number of MyRepublic customers in Depok West Java was 8,600 customers of which 6,800 have been subscribing for more than 1 year. The sample in this research was 200 .

\subsection{Data Collection and Analysis}

This research used quantitative data, while the sources of data were obtained from primary data and secondary data. The data collection method used in this research was questionnaire. The analysis technique used was SEM. In this research, the researchers distributed questionnaires directly to the customers who use broadband internet and digital television services from MyRepublic. Distribution of user questionnaires was to find out their opinions about price, service quality, information quality on customer satisfaction and customer commitment. In addition to the questionnaire, literature research was also performed by collecting data from books, previous research journals, and other literature related to research material. It was a correlation research.

\subsection{Demographic Information}

In this research, the respondents were 200 of MyRepublic customers who had been subscribing for more than 1 year. Characteristics of the respondents based on age were dominated by age 31-40 amounted to 83 people or $41.5 \%$ 
of the total respondents and the smallest respondent was above the age category of 7 people or $14 \%$ of the total respondents. From the research results, 159 people or $79 \%$ were men and 41 people or $21 \%$ were women. This can be indicated that men were more dominant in terms of making decisions related to technology. MyRepublic Fixed Broadband internet service users are family, this is indicated by 160 respondents or $80 \%$ are married. 145 or $74.5 \%$ of respondents with S1 / S2 / S3 education are interested in fast internet. The occupation of the respondents are mostly employees of 105 or $52.5 \%$. 83 or $41.5 \%$ with the highest income 6 million to 8 million. So that it can be concluded that MyRepublic services are more enjoyed by customers who have high socioeconomic status. 43 respondents or $46.5 \%$ have been subscribing for between 1 and 2 years.

\subsection{Result and Discussion}

\subsection{Result}

\subsubsection{Analiysis Full Model}

Statistical tests conducted for the Goodness of Fit analysis are shown in table 1:

\begin{tabular}{|c|c|c|c|c|}
\hline \multirow{2}{*}{ Measures of Goodness of Fit } & \multicolumn{2}{|c|}{ Measure of match } & \multirow{2}{*}{\multicolumn{2}{|c|}{ Measurement results }} \\
\hline & Good fit & Marginal fit & & \\
\hline Goodness of Fit Index(GFI) & $\geq 0,90$ & $0.80-<0.90$ & 0.810 & Marginal fit \\
\hline Root Mean Square Error (RMSEA) & $<0.08$ & & 0.038 & Good fit \\
\hline Normed Chi2/df & $<2.00$ & & 1.506 & Good fit \\
\hline Normal Fit Index (NFI) & $\geq 0,90$ & $0.80-<0.90$ & 0.880 & Marginal fit \\
\hline Non-Normed Fit Index (NNFI) & $\geq 0,90$ & $0.80-<0.90$ & 0.970 & Good fit \\
\hline Relative Fit Index (RFI) & $\geq 0,90$ & $0.80-<0.90$ & 0.870 & Marginal fit \\
\hline Comparative Fit Index (CFI) & $\geq 0,90$ & $0.80-<0.90$ & 0.970 & Good fit \\
\hline Incremental Fit Index (IFI) & $\geq 0,90$ & $0.80-<0.90$ & 0.970 & Good fit \\
\hline Parsimony Normed Fit Index (PNFI) & $\geq 0,90$ & $0.80-<0.90$ & 0.810 & Marginal fit \\
\hline
\end{tabular}

\section{Source: Primary Data Process (2019)}

Based on SEM analysis results, the GFI value is 0.81 (marginal fit) because it is close to 0.90, the RMSEA value is $0.050<0.038$ (model fit). Thus, it can be said that the structural equation model meets the absolute fit measure requirements, which means that the structural equation model in this research overall is compatible with the data. In the incremental fit measure requirements, NFI value is 0.880 (marginal fit), CFI $0.970 \geq 0.90$ (model fit), IFI $0.970 \geq 0.90$ (model fit), RFI $0.870 \geq 0.90$ (marginal fit), and NNFI $0.970 \geq 0.90$ (model fit), indicating that the structural equation model meets the incremental fit measure requirements. For the parsimonious fit measure requirement, the normed chi-square value of $1.506<2.0$ (model fit) and PNFI value 0.81 (marginal fit), shows that the structural equation model meets the parsimonious fit measure requirements which means that overall the structural equation model in this research has conformity comparative to the baseline model (null model). Therefore, it can be concluded that the suitability of the predicted model with observational values meets the requirements. By this reason, it is concluded that this research model meets the size of the model's suitability (goodness of fit) and can be continued to further analysis, which is testing the hypothesis.

The following figure is displayed based on the standard solution and the overall figure based on the $t$ value Full Model as a whole: 


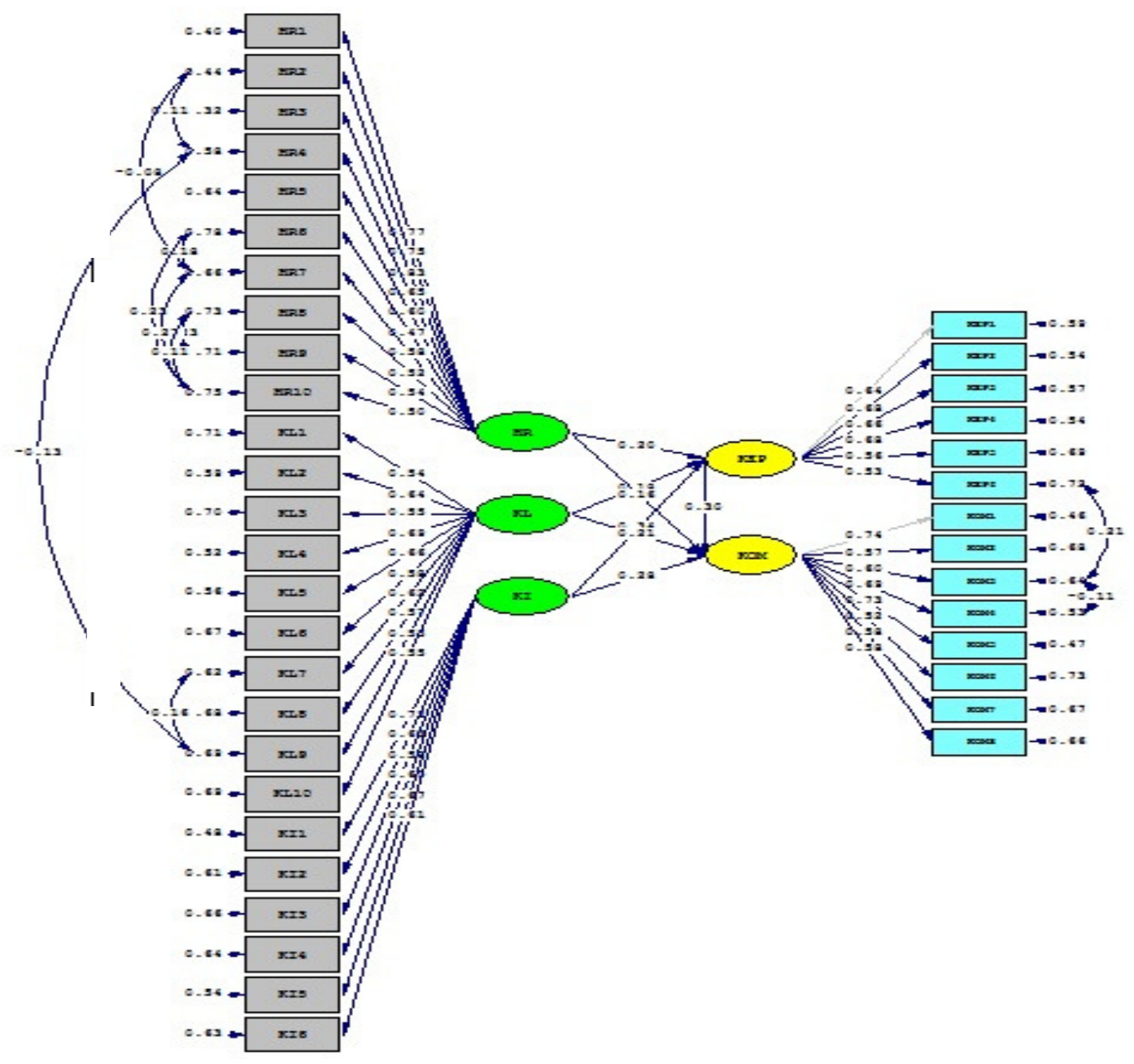

Figure 2 Overall Basic Model Based on Standard Solution Source: Primary Data Processed (2019) 


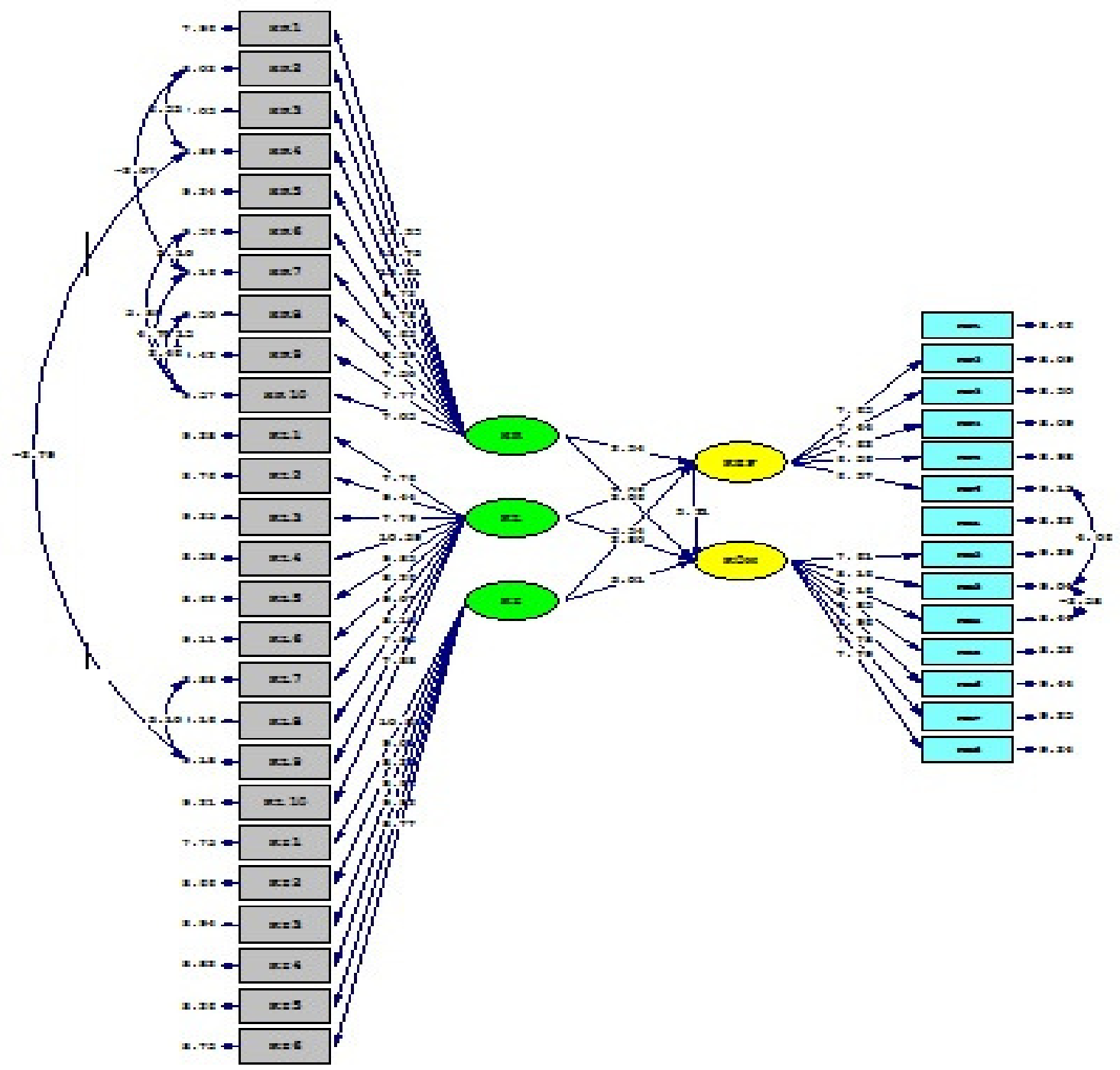

Figure 3 Overall Basic Model Based on Standard Solution

Source: Primary Data Processed (2019)

\subsubsection{SEM Validity and Reliability Tests}

The test results of validity and SEM reliability on the variables tested can be concluded in table 2:

\begin{tabular}{|l|c|c|}
\hline \multicolumn{1}{|c|}{ Variable } & $\mathbf{C R}^{\mathbf{2}}$ & $\mathbf{V E}^{\mathbf{2}}$ \\
\hline Price & 0,86 & 0,40 \\
\hline Service quality & 0,85 & 0,36 \\
\hline Information quality & 0,80 & 0,41 \\
\hline Customer satisfaction & 0,79 & 0,39 \\
\hline Customer commitment & 0,84 & 0,40 \\
\hline
\end{tabular}

Source: Primary Data Processed (2019)

The construct reliability (CR) value of all variables is greater than 0.70 and the variance extracted (VE) value of 0.41 is lower than 0.50. Butarbutar (2015) stated that the value of AVE which is below 0.5 does not cause concern and can be accepted because the results of AVE are frequently below 0.5 in previous research. By this reason, it can be concluded that each indicator forming latent variables has good reliability. Therefore, all indicators in this research model have a significant positive effect on latent variable in price.

\subsubsection{Suitability Analysis Structural Model (Causal Relations)}

Based on the primary data processing of this research using the Maximum Likelihood (ML) rule, a structural equation was produced as can be seen in Figure 4 on the t-value structural model path diagram. 




Figure 4. Flow Chart of t-value Structural Model

Source: Primary Data Processed (2019)

\section{Structural Equations}

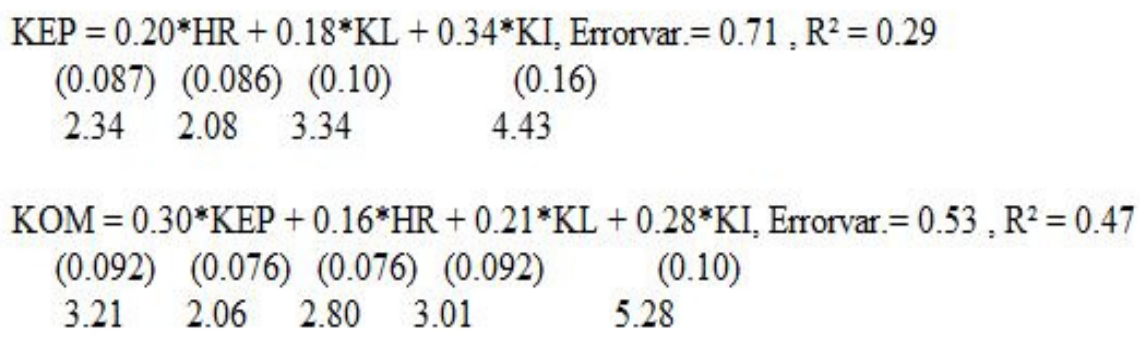

Source: Primary Data Processed (2019)

Figure 5. Output of Structural Equation Model

R Square (R2) or determinant coefficient of 0.29 or $29 \%$ indicates that customer satisfaction was affected by the three variables of price, service quality, and information quality and still had effects from other factors of $71 \%$ by other unexamined variables in this research. R Square (R2) or determinant coefficient of 0.47 or $47 \%$ indicates that customer commitment was affected by customer satisfaction, price, service quality, and information quality variables and still had effects from other factors of $53 \%$ by other unexamined variables in this research.

\subsubsection{Analysis of Direct and Indirect Effects}

The indirect effect of customer commitment variables on price, service quality, and information quality variables can be seen in Figure 6 on flow chart of the standardized solution structural model.

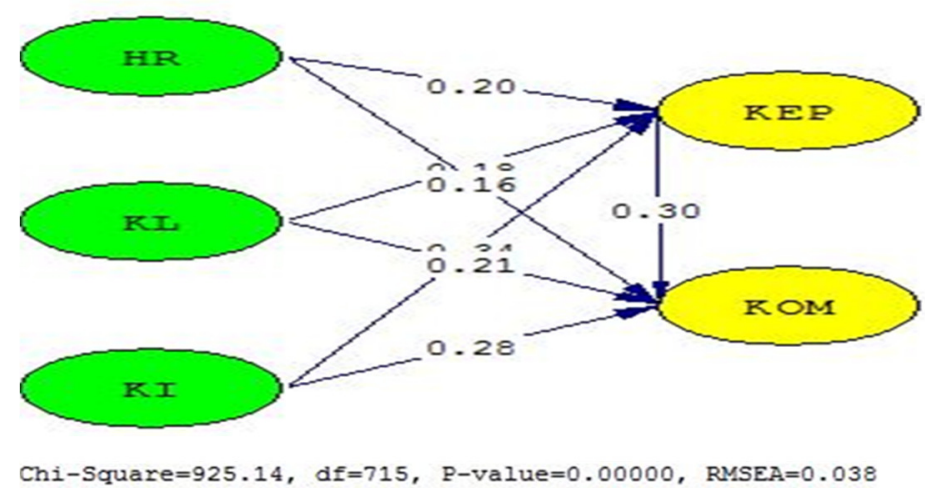

Source: Primary Data Processed (2019)

Figure 6. Output of Indirect Effects 


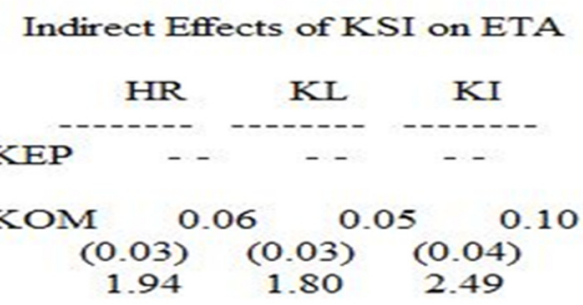

Source: Primary Data Processed (2019)

Figure 7. Output of Indirect Effects

Price and service quality had an indirect effect on customer commitments with t-values of 1.94 and 1.80 and below 1.96 , so that they had poor value of validity that results in variable prices and service quality which are indirect effects can be ignored. While the effect of service quality had a t-value of 2.49 above 1.96. Thus, there was an indirect effect of the information quality variable on customer commitment.

\subsubsection{Hypothesis Test}

The results of t-value and the structural equation coefficient used to test this hypothesis can be seen in table 3 as follows:

\begin{tabular}{|c|c|c|c|c|}
\hline Hypothesis & Structural Path & t-value & Information & Conclusion \\
\hline H1 & $\begin{array}{l}\text { Price }==>\text { Customers } \\
\text { Satisfaction }\end{array}$ & 2,34 & Hypothesis Accepted & $\begin{array}{l}\text { There is an influence of price on } \\
\text { customer satisfaction. }\end{array}$ \\
\hline $\mathrm{H} 2$ & $\begin{array}{l}\text { Service Quality }==> \\
\text { Customers Satisfaction }\end{array}$ & 2,08 & Hypothesis Accepted & $\begin{array}{l}\text { There is an influence of service } \\
\text { quality on customer satisfaction. }\end{array}$ \\
\hline $\mathrm{H} 3$ & $\begin{array}{l}\text { Information Quality }==> \\
\text { Customers Satisfaction }\end{array}$ & 3.34 & Hypothesis Accepted & $\begin{array}{l}\text { There is an influence of information } \\
\text { quality on customer satisfaction. }\end{array}$ \\
\hline $\mathrm{H} 4$ & $\begin{array}{l}\text { Price }==>\text { Customers } \\
\text { Commitment }\end{array}$ & 2,06 & Hypothesis Accepted & $\begin{array}{l}\text { There is an influence of price on } \\
\text { customer commitment. }\end{array}$ \\
\hline H5 & $\begin{array}{l}\text { Service Quality }==> \\
\text { Customers Commitment }\end{array}$ & 2,80 & Hypothesis Accepted & $\begin{array}{l}\text { There is an influence of service } \\
\text { quality on customer commitment. }\end{array}$ \\
\hline H6 & $\begin{array}{l}\text { Information Quality }==> \\
\text { Customers Commitments }\end{array}$ & 3,01 & Hypothesis Accepted & $\begin{array}{l}\text { There is an influence of service } \\
\text { quality on customer commitment. }\end{array}$ \\
\hline $\mathrm{H} 7$ & $\begin{array}{l}\text { Customers Satisfaction } \\
==>\text { Customers } \\
\text { Commitment }\end{array}$ & 3,21 & Hypothesis Accepted & $\begin{array}{l}\text { There is an influence of customer } \\
\text { satisfaction on customer } \\
\text { commitment. }\end{array}$ \\
\hline
\end{tabular}

Source: Primary Data Processed (2019)

Table 3 shows that there are seven justifications of the research hypothesis that have been compiled by researchers. Each hypothesis shows a positive and significant correlation between each variable and the hypothesis.

\subsection{Discussion.}

\subsubsection{Discussion of the Findings}

The following is a discussion of the findings obtained from the results of this research.

1. The correlation between Price and Customer Satisfaction of Fixed Internet Broadband Operator MyRepublic Based on the results of SEM analysis, it can be seen that the price has a positive and significant effect on customer satisfaction. This is evidenced from the results of the $t$ test obtained $t$ value of 2.43. Because the value of $t>1.96$, it can be concluded that the price has a significant effect on customer satisfaction. It means that the more precise the price, the higher the customer satisfaction. Thus, the first hypothesis can be accepted.

2. The correlation between Service Quality and Customer Satisfaction of Fixed Internet Broadband Operator MyRepublic

Based on SEM analysis results, it can be seen that service quality has a positive and significant effect on customer satisfaction. This is evidenced from the results of the $t$ test obtained $t$ value of 2.08 . Because the $t$ value $>$ 1.96 , it can be concluded that service quality has a positive and significant effect on customer satisfaction. It means that the better quality of service, the higher customer satisfaction. Thus, the second hypothesis can be accepted.

3. The correlation between Information Quality and Customer Satisfaction of Fixed Internet Broadband Operator MyRepublic

Based on the results of SEM analysis, it can be seen that the quality of information has a positive and significant effect on customer satisfaction. This is evidenced from the results of the $t$ test obtained $t$ value of 3.34. Because the $t$ value $>1.96$, it can be concluded that the quality of information has a positive and significant effect on customer satisfaction. It means that the better quality of information, the higher customer satisfaction. Thus, the third hypothesis can be accepted. 
4. The correlation between Price and Commitment of Fixed Internet Broadband Operator MyRepublic Based on the results of SEM analysis, it can be seen that the price has a positive and significant effect on customer commitment. This is evidenced from the results of the $t$ test obtained t value of 2.06 . Because the value of $\mathrm{t}>1.96$, it can be concluded that the price has a positive and significant effect on customer commitment. It means that the more appropriate price, the customer commitment increases. Thus, the fourth hypothesis can be accepted.

5. The correlation between Service Quality and Customer Commitment of Fixed Internet Broadband Operator MyRepublic

Based on the results of SEM analysis, it can be seen that service quality has a positive and significant effect on customer commitment. This is evidenced from the results of the $t$ test obtained t value of 2.80 . Because the $t$ value $>$ 1.96 , it can be concluded that service quality has a positive and significant effect on customer commitment. It means that the better quality of service, the customer commitment increases. Thus, the fifth hypothesis can be accepted.

6. The correlation between Information Quality and Customer Commitments of Fixed Internet Broadband Operator MyRepublic

Based on the results of SEM analysis, it can be seen that the quality of information has a positive and significant effect on customer commitment. This is evidenced from the results of the $t$ test obtained $t$ value of 3.01 . Because the $t$ value $>1.96$, it can be concluded that the quality of information has a positive and significant effect on customer commitment. It means that the better quality of information, the customer commitment increases. Thus, the sixth hypothesis can be accepted.

7. The correlation between Customer Satisfaction with Customer Commitment of Fixed Internet Broadband Operator MyRepublic

Based on the results of SEM analysis, it can be seen that customer satisfaction has a positive and significant effect on customer commitment. This is evidenced from the results of the $t$ test obtained $t$ value of 3.21. Because the $t$ value $>1.96$, it can be concluded that customer satisfaction has a positive and significant effect on customer commitment. It means that the higher customer satisfaction, the customer commitment increases. Thus, the seventh hypothesis can be accepted.

\subsubsection{Discussion of Indirect Effects}

The findings in the research indicate that there is an indirect correlation between the price, service quality, and information quality variables on customer commitment. The analysis illustrates that the indirect correlation between the quality of information with customer commitment is $10 \%(0.10)$ with t-value of 2.49. Price has an indirect correlation to customer commitment of $6 \%(0.06)$ and service quality has an indirect correlation to customer commitment of $5 \%(0.05)$ but both have t-value lower than 1.96 , so it can be ignored.

This shows that the most direct correlation between the quality of information with customer commitment is greater than the indirect correlation. Meanwhile, the price and quality of service has an indirect correlation to customer commitment. However, these variables cannot affect them to subscribe in the long run. The effective aspects to make it true is to provide clear and quality information.

\section{Conclusion}

Based on the research results, it can be concluded several important things:

1. Price has a significant and positive correlation to the customer satisfaction in Fixed Internet Broadband of MyRepublic. This is evidenced by the t-value 2.34 greater than 1.96 and the correlation coefficient of 0.20 . It means that the price provided is adjusted price to the purchasing power of the customer, so that it can increase customer satisfaction.

2. Service quality has a significant and positive relationship to the customer satisfaction in Fixed Internet Broadband of MyRepublic. This can be seen from the t-value of 2.08 that is greater than 1.96 and the correlation coefficient value of 0.18 . By performing an increase in service quality to customers, it will be able to increase the level of customer satisfaction resulting in a reduction in the number of customers who unsubscribe.

3. Information has a significant and positive correlation to the customer satisfaction in Fixed Internet Broadband of MyRepublic. This can be seen from the t-value of 3.34 that is greater than 1.96 and the correlation coefficient value of 0.34 . The fast and accurate quality of information affects the level of customer satisfaction, so that it can reduce the number of unsubscribed customers.

4. Price has a significant and positive relationship to the customer commitment in Fixed Internet Broadband of MyRepublic. This can be seen from the t-value of 3.21 that is greater than 1.96 and the correlation coefficient is of 0.30. By determining the appropriate price to the customer, it will be able to increase the customer commitment in a long period of time.

5. Quality of service has a significant and positive correlation to the customer commitment in Fixed Internet Broadband of MyRepublic. This can be seen from the t-value of 2.80 that is greater than 1.96 and the correlation coefficient value of 0.21 . The better quality of the services provided, the higher the customer commitment, and 
therefore the number of unsubscribed customers will decrease.

6. Quality of information has a significant and positive correlation to customer commitment in Fixed Internet Broadband of MyRepublic. This can be seen from the t-value 2.80 that is greater than 1.96 and the correlation coefficient value of 0.21 . The quality of information provided effectively and quickly to the customers can maintain customer commitment, so that the customers remain loyal using the MyRepublic service.

7. Customer satisfaction has a significant and positive correlation to the customer commitment in Fixed Internet Broadband of MyRepublic. It can be seen from the t-value of 2.06 that is greater than 1.96 and the correlation coefficient value of 0.16 . The higher level of customer satisfaction supported by an affordable price, improved service quality, and good quality information will increase the customer commitment to subscribe to products of MyRepublic in a long period of time.

\section{References}

Alhasanah, Jihan Ulya. (2014). "Pengaruh Kegunaan, Kualitas Informasi dan Kualitas Interaksi Layanan Web ECommerce Terhadap Keputusan Pembelian online”. Jurnal Administrasi Bisnis (JAB) Vol. 15 No. 2. Universitas Brawijaya. Malang

A,O'brien , James, (2006), Introducing To Information System. Jakarta: Salemba. Empat.

Asosiasi Penyelenggara Jasa Internet Indonesia. Hasil Survey Penetrasi dan Perilaku Penguna Internet Indonesia 2017. https://www.apjii.or.id/ content/read/39/342/Hasil-Survei-Penetrasi-dan-Perilaku-Pengguna-InternetIndonesia-2017

Butarbutar, Dicky John Anderson. (2015). "Analisa Kualitas dan Kepuasan Pengguna Terhadap Keinginan Mengunjungi Kembali WEB Pada Situs WEB Kapanlagi.com”. Jurnal Bisnis, Management \& Ekonomi Fakultas Bisnis dan Manajemen. Bandung: Universitas Widyatama.

Capel Dan Ndubisi (2011), "The Antecedents of Relationship Quality in Malaysia And New Zealand". International Journal of Quality \& Reliability Management, 28(2), 233-248

Ellena, Frieda. (2011). "Analisis Pengaruh Kepercayaan, Komitmen, Komunikasi, Dan Penanganan Keluhan Terhadap Loyalitas Nasabah”. Tesis. Fakultas Ekonomi. Universitas Diponegoro Semarang.

Fandy Tjiptono, (2002). Manajemen Jasa. Penerbit Andi Yogyakarta.

Foster, Bob. (2016). "The Effect of Price and Service Quality on Customer Satisfaction in Mutiara Hotel Bandung". American Research Journal of Humanities and Social Sciences Volume 2016, 12 Pages

Hosang, Dkk. (2016). “Analisis Pengaruh Kualitas Pelayanan Dan Harga Terhadap Kepuasan Pasien (Studi Kasus Pada Rumah Sakit Siloam Manado)”. Jurnal Berkala Ilmiah Efisiensi, Volume 16 No. 01 Hal 159-171

J.Setiadi, Nugroho. (2008). Perilaku Konsumen. Jakarta: PT Kencana

Kotler, Philip., \& Keller, Kevin Lane. (2008). Marketing Management (13th Ed.). Prentice Hall Ptr.

Nasution. (2004). Manajemen Jasa Terpadu. Jakarta: Ghalian Indonesia.

Parasuraman, A., Berry, L.L., \& Zeithaml, V.A. 1988. "SERVQUAL: A Multiple-item Scale for Measuring Customer Perceptions of Service Quality". Journal of Retailing, 64(1): 12-40.

Putri, Kadek Indri Novitas Sari Putri \& Nurcaya, I Nyoman. (2013). "Pengaruh Kualitas Pelayanan Jasa Terhadap Kepuasan Pelanggan D \& I Skin Centre Denpasar”. E-Jurnal Manajemen, Universitas Udayana Vol. 2, No. 8. Hal:918-937

Saidani, Basrah Dan Samsul Arifin, (2012). "Pengaruh Kualitas Produk Dan Kualitas Layanan Terhadap Kepuasan Konsumen Dan Minat Beli Pada Ranch Market”. Jurnal Riset Manajemen Sains Indonesia (Jrmsi), Vol. 3, No. 1, 2012

Setyo, Pe. (2017). "Pengaruh Kualitas Produk Dan Harga Terhadap Kepuasan Konsumen Best Autoworks". Jurnal Manajemen Dan Start-Up Bisnis Volume 1, Nomor 6, Februari 2017: 755 - 764

Zahra Ehsani, Mohammad Hossein Ehsani, (2014). "Effect of Quality and Price on Customer Satisfaction and Commitment in Iran Auto Industry”. International Journal of Service Science, Management and Engineering. Vol. 1, No. 5, 2014, Pp. 52-56. 